\title{
The Oxford Handbook of Adaptation Studies
}

LEITCH, Thomas, ed.: The Oxford Handbook of Adaptation Studies. New York: Oxford University Press, 2017. Oxford Handbooks. 784 s.

Při prvním listování vyvstává dojem, že se tato knížka objevuje v celkem zajímavé chvíli. Pro čtenáře uvedené do oblasti adaptace je to konec dlouholeté debaty o tom, jestli by se adaptační studia měla omezit pouze na pozorování vztahů mezi literaturou (románem) a filmem, anebo by měla zahrnout další intermediální přesahy. Čtenář-laik by však vycházel z obecně známého faktu, že digitální doba vytváří zcela nové chápání nejen adaptace jako takové (viz Adaptace 3,0 níže), a svým způsobem nás nutí k přehodnocení všech aspektů dnešní doby. V obou případech lze tuto publikaci vnímat jako jistou rekapitulaci myšlení o adaptaci a rovněž, jak napovídá samotný název, jako učebnici nebo příručku pro všechny zájemce o tuto oblast.

Již na začátku je třeba brát v úvahu, že se jedná o neobvykle ambiciózní projekt, který vyústil $\mathrm{v}$ dosud nejrozsáhlejší soubor odborných textů věnovaných adaptaci, na nichž se podílejí jedni z předních badatelů v této disciplíně, včetně Kamilly Elliottové, Roberta Stama, Davida T. Johnsona, Petera Leva aj. O záměru publikace vypovídají i cíle, jež si redaktor Thomas Leitch klade v úvodu: podrobně vyložit vývoj disciplíny od počátků do dnešního dne, poskytnout široký záběr jejích metodologií a přistupů a pokusit se o nastavení budoucí vývojové linie adaptačních studií. Redaktor je přitom velice kritický a vědomý si i těch nejsubtilnějších tendencí v této oblasti. Na základě předložených statí se například domnívá, že v myšlení o adaptaci lze rozlišovat mezi dvěma proudy, a to kontinentálněevropským a anglo-americkým. Prvnímu proudu totiž připisuje hodnotící, deduktivní přístup (shora-dolů) typický pro evropskou literární vědu, estetiku a intermediální studia, kde se odborníci pod vlivem prostorového myšlení (mapy, grafy a stromy) snaží adaptačním studiím přidělit místo v mozaice humanitních disciplín. Pro anglo-americký proud je podle Leitche 
příznačný analytický, induktivní přístup (empirický př́ístup zdola-nahoru), jako i tzv. časové chápání adaptačních studií (pocházející pravděpodobně z oborů, jako jsou antropologie, kulturologie, sociologie a orální historie), kde se badatel zaměřuje na příběhy a historie adaptací, jež mohou existovat souběžně.

Neméně důležitý a přínosný je Leitchův návrh na rozdělení myšlení o adaptaci i adaptačních studií na období. Jako konec prvního období (tzv. Adaptace 0,0) určuje Leitch publikaci studie Od románu k filmu od Georgea Bluestonea (Novels into Film, 1957) - do této chvíle podle něho byla adaptační praxe téměř nezkoumaná až na jednotlivé poznámky různých autorů na okraji jiných aktivit a textů. Předmětem zájmu Adaptace 1,0 byla podle Leitche otázka věrnosti, tedy do jaké míry filmový přepis zrcadlí literární podobu. Interpretační pole disciplíny se značně rozšiřuje za Adaptace 2,0 (stěžejní studie je Teorie adaptace od Lindy Hutcheonové z roku 2006), kdy se pomocí intertextuality jakožto teoretického modelu adaptační studia otevírají $\mathrm{k}$ adaptacím všelijakého druhu s důrazem na intermediální transpozici. Poslední období, Adaptace 3,0, které přetrvává dodnes, se spojuje s nástupem tzv. digitální doby, v níž se podle odborníků dosavadní gramotnost „jen pro čtení“ (Read-Only Literacy) rychle nahrazuje tzv. gramotností „pro čtení i psani““ (Read-Write Literacy), a tím se radikálně mění lidský pohled na umění a kulturu, v neposlední řadě i na adaptaci.

Takto nastavená publikace podává čtyřicet odborných statí rozdělených do sedmi tematických kapitol; zatímco první tři jsou věnovány obecnému vymezení adaptace jako takové nebo tradičním adaptačním praxím (adaptaci literárních klasiků apod.), autoři textů ve čtvrté, páté a šesté kapitole pojednávají o pozoruhodném množství žánrových variací, ${ }^{1}$ jako i o vztahu mezi adaptačními studii a jinými koncepcemi a disciplínami. ${ }^{2} \mathrm{~V}$ první skupině textů je patrná snaha o různorodost a začlenění co nejvíce žánrů a podžánrů bez předsudků minulé doby (adaptace totiž není pouze filmový přepis románového textu), v druhé skupině autoři opakovaně vyzývají k užší spolupráci mezi obory, která

1) Zatímco některé $z$ žánrů jsou již tradičně zkoumány v jiných disciplínách (opera a rozhlas), některé jsou téměř opomenuty, anebo se nedávno staly předmětem zájmu (komiks a videohry). Pojednání I. Q. Huntera o adaptaci a pornografii, které se však dotýká i „vážnějších“ témat jako ideologie, lze považovat za odvážný posun $\mathrm{k}$ inovativnímu přístupu $\mathrm{v}$ rámci adaptačních studií.

2) Texty v 5. kapitole vycházejí často z koncepce intertextuality, s níž jsou úzce spojeny disciplíny jako intermedialita, translatologie a interaktivní média. 6. kapitola pak zapojuje tradičnější humanitní disciplíny a oblasti - dějiny, politiku, ideologii. Studie Lawrence Rawa o srovnání a propojení výzkumů translatologie a adaptačních studií je jeden z mála návrhů tohoto druhu, který se navíc úspěšně vyhýbá Jakobsonově již mnohokrát exploatovanému konceptu intersémiotického překladu nebo transmutace. Studie Petra Bubeníčka se pak jeví jako povedený př́íklad, jak se při soustředěné analýze jistých posunů dá úspěšně pracovat s velkým množstvím primárních a sekundárních zdrojů pozitivistické provenience. 
by měla vést $\mathrm{k}$ sjednocení výsledků. Obecně vzato, přestože se většina těchto textů zabývá konkrétním případem, i přes skepsi vyjádřenou v úvodu ${ }^{3}$ lze konstatovat, že se nejedná o pouhá srovnávací cvičení vyhovující požadavkům akademické byrokracie na pracovištích jejich autorů, nýbrž o promyšlené případové studie s jasně zadanými tezemi a obecnějšími implikacemi. Některé texty, jako jsou studie Renaty Kobetts Millerové o divadelních adaptacích románu v 19. století nebo článek Wendy Zierlerové o adaptacích biblického mýtu o Mojžíšovi, $\mathrm{k}$ publikaci tohoto druhu patří právě díky své úvodní povaze. ${ }^{4}$ Vzorový př́klad moderní případové studie dále představuje článek Dennise R. Perryho: pojednání o filmových adaptacích Frankensteina se totiž vyznačuje neobvyklou vlídností, podávání informací místy působí jako povídka a tím se vymaňuje ze sterility akademického diskurzu. Závěrečná kapitola přináší širokou škálu otázek týkajících se budoucnosti adaptačních studií, a to v oblasti teorie, metodologie a didaktiky.

Vzhledem ke vždy vysokým standardům edice, v níž vyšla (Oxford Handbooks), po jazykové, technické nebo vizuální stránce této publikaci nelze nic vytknout. Případnou kritiku je tak možné směřovat spíše na samotná adaptační studia, kde lze sledovat několik tendencí. Zaprvé je příznačný jistý rozpor mezi výše zmíněnými proudy v adaptačních studiích, který je ne vždy produktivní dochází tak např́klad $\mathrm{k}$ duplicitní terminologii pro stejné nebo podobné jevy (srov. „transmediální/transkulturní transpozice“ vs. „ekonomičtější adaptace“), metodologie, které by se měly vzájemně doplňovat, se vzájemně vylučují apod. Další potenciální problém shledáváme v omezeném kulturním působení disciplíny, která se až na výjimky zaměřuje na příklady z tzv. „západní“ nebo dokonce „anglo-americké“ kultury a v důsledku působí převážně v tomto kontextu. ${ }^{5}$ Disciplíny jako performanční studia a moderní divadelní věda se v tomto ohledu nechaly inspirovat i neevropskými praktikami ${ }^{6}$ a tím obohatily nejen svoji teorii a metodologii, ale i současné tvưrce (divadelníky, producenty, scénáristy aj.) o nepřehledné množství podnětů.

3) Thomas Leitch uvádí esej Roberta Raya z roku 2000, v níž kromě sebeúčelnosti předmětem kritiky případových studií jsou též omezenost jejich výsledků a teoretických implikací, jako i omezení formy a/nebo obsahu „akademickou ekonomikou“.

4) Podobně vyznívá i článek Williamse B. Jonese Jr. o adaptaci klasických literárních děl do komiksové podoby.

5) Př́iklady, z nichž čerpá drtivá většina studií zařazených do Leitchova souboru, pocházejí převážně z děl (literárních, filmových, divadelních, výtvarných apod.) tzv. západního kánonu, nebo jsou obecně spojeny s kulturou západní Evropy a Ameriky. Pochopitelně, přední místo v takovém „adaptačním kánonu“ zaujímají hollywoodská produkce a artefakty západní populární kultury jako komiks.

6) Srov. dílo amerického divadelníka a teatrologa Phillipa B. Zarrilliho, jehož poznatky z východních divadelních tradic (zvláště japonské divadlo) současně ovlivňují nejen moderní divadlo a performanci, ale i koncepce současné divadelní vědy. 
Nakonec $\mathrm{v}$ úvodu zmíněná institucionalizace ${ }^{7}$ adaptačních studií se může jevit jako dvojsečná. Na jednu stranu podpora ze strany akademického prostředí umožní větší propagaci a popularizaci tohoto oboru mezi studenty, pečlivě řízená výuka adaptačních studií navíc může být nesmírně podnětná i pro badatele. $\mathrm{Na}$ druhou stranu akreditovaný studijní program nebo vědecký grant nezřídka vyžadují sjednocenou a přesně určenou metodologii, jako i jednoznačné výsledky. Jinými slovy pokrokovost nové oblasti školitelům nemusí bránit, aby nadále aplikovali metodiku již ustálenou a pro nový kurz spíše nevhodnou, zatímco grantem (a tím i přísnými časovými a jinými požadavky technické povahy) podmíněný výzkum se nezřídka uzavírá do začarovaného kruhu úzce omezených sond a prověřených teoretických modelů. Zde tedy jako u jiných disciplín může být akademická uniformita na úkor hledání plurality pravdy, což tvoří (přinejmenším dosud) jednu z hlavních hodnot adaptačních studií.

Dime Mitrevski

7) V tomto směru se Thomas Leitch zmiňuje nejen o podpoře odborných publikací a periodik, jako i konferencí věnovaných adaptaci jako takové, o schvalování vědeckých grantů pro rozvoj této oblasti, ale i o vytváření specializovaných předmětů ba dokonce studijních předmětů z adaptačních studií na akademických pracovištích, a to za účelem obdržení statusu plnohodnotné akademické disciplíny. 